\title{
The Effect of Exercise on Balance: Emphasis on Women Diagnosed with Parkinson's Disease
}

\author{
B Rhett Rigby ${ }^{1}$ and Ronald Davis ${ }^{2 *}$ \\ ${ }^{1}$ Department of Kinesiology, Texas Woman's University, USA \\ ${ }^{2}$ Department of Kinesiology, Texas Woman's University, USA
}

Submission: February 01, 2017 ; Published: February 17, 2017

*Corresponding author: Ronald Davis, Department of Kinesiology, Texas Woman's University, Denton, TX 76204-5647, USA,

Tel: 940-898-2589; Fax: 940-898-2581; Email: rdavis4@mail.twu.edu

\begin{abstract}
The motor symptoms associated with Parkinson's disease include tremors, dyskinesis, rigidity, and posture and gait abnormalities. The incidence, prevalence and mortality rates of the disease are lower in women compared to men, possibly due to the neuroprotective role of estrogen. Aerobic, resistance and flexibility exercise protocols may be effective at improving the functional limitations, including balance, that are a result of the inherent pathophysiology of Parkinson's disease. Resistance exercise that targets lower torso, pelvic and leg muscles elicits strength changes that allows for better control of posture and balance, thereby potentially lessening chronic fatigue and preventing falls.

Keywords: Parkinson's disease; Women; Female; Exercise; Balance; Aerobic; Resistance; Balance; Fatigue; Bone mineral density

Abbreviations: PD: Parkinson's Disease; BMD: Bone Mineral Density
\end{abstract}

\section{Introduction}

Parkinson's disease (PD) is a neurodegenerative condition caused by a reduction in dopaminergic neurons located in the substantia nigra of the brain [1]. The disease is characterized by muscle tremors, rigidity, and dyskinesis leading to posture and gait abnormalities [1]. Although the incidence ratio of males to females is approximately 1.46 [2], the prevalence of PD among men is doubled when compared to women [3]. Females typically have a lower mortality rate associated with PD due to: 1) the overall longer life expectancy when compared to men in the general population, and; 2) the factors that predict high mortality in those with $\mathrm{PD}$, including cognitive impairment and posture and gait abnormalities, are less common in women [4-6].

In males, there is therefore a greater predisposition to develop PD [7]. This bias may be due to the molecular pathology of PD. Gene expression profiles in normal substantia nigra dopaminergic neurons are sex- specific and the survivability of these neurons are dependent on molecular pathways that are very different in men and women [7]. Therefore, women are thought to have greater protection from PD when compared to men, which may be due to estrogen concentrations [7].
Estrogen plays a significant role in the pathophysiology and progression of PD in women. Estrogen influences dopamine synthesis and release while inhibiting dopamine uptake [8]. The higher concentrations of estrogen is a possible reason for the more benign phenotype in women when compared to men $[9,10]$, particularly before a course of medication has begun [11]. Estrogen may have a protective effect, preventing toxins from negatively affecting and possibly degrading neurons in the substantia nigra [8]. However, the protective effect of estrogen was not evident in other studies, which included women participants who reported a more rapid onset of symptoms, including dyskinesis, upon diagnosis [12-14].

With regard to motor symptoms, women typically present more with tremors [9] and dyskinesis, but not rigidity [15], when compared to men. Upon the analysis of non-motor symptoms, constipation, restless legs, pain and emotional characteristics such as nervousness and sadness were more prevalent in women [15-17]. A reduction in visuospatial cognition also occurs more frequently in women [11]. When compared to women without PD, women with PD typically report a more frequent loss of interest and anxiety [18]. 


\section{Effect of Aerobic Exercise on Balance}

Genders are not analyzed separately in the majority of studies that include exercise as an intervention to investigate functional changes, including balance, in adults with PD. Several studies have included a large number of female participants with PD. Cakit et al. [19] reported significant improvements in the scores on the Berg Balance Scale following 8 weeks of treadmill training in which intensity was incrementally increased using speed in 31 individuals (15 females) with PD [19]. In another study, no difference in functional reach scores [20,21] were reported between a traditional aerobic exercise program, a flexibility program, and a home-based exercise program after 16 months in 121 adults (45 females) with early- to mid-stage PD [22]. Other non-conventional forms of aerobic exercise have demonstrated improvements in balance, such as robotic gait training [23], dance therapy [24-26], boxing training [27] and whole-body vibration [28] in both women and men with PD.

\section{Effect of Spinal Flexibility and Resistance Exercise on Balance}

Poor spinal flexibility is moderately correlated with functional limitations in those with PD [29]. Using regression analysis, Shenkman et al. [29] founda greater correlation between females with PD and both poor spinal flexibility and balance [29]. Balance in humans is often correlated with postural control [30]. In fact, many of the same tools are used to assess both posture and balance. When assessing lower limb strength, Pääsuke et al. [31] found differing reaction times and maximum isometric force between the legs in females with PD [31]. This may be due to the postural asymmetry, and thus balance impairment, that is prevalent with PD.In a group of 20 adults (7 women) with $\mathrm{PD}$, power in the leg muscles (i.e., leg extensors, knee flexors, hip extensors, hip abductors) was significantly increased after 12 weeks of resistance exercise, leading to improvements with stepping reaction time, maximal balance range and time in single leg stance [32].

\section{Exercise, Balance, and Fatigue}

To achieve proper balance, the muscles that control and regulate balance must be strengthened through force generation within the skeletal muscles. The generation of necessary force from motor tasks, coupled with the power loss in muscle due to bradykinesia and tremors, may lead to fatigue in those with PD [33-35]. However, there is an inverse relationship between the frequency of regular aerobic exercise and chronic fatigue both women and men with PD [36].

\section{Exercise, Balance, and Bone Mineral Density}

Postural instability and poor balance, in addition to other neuromuscular and visual impairments, are significant and independent risk factors for hip fracture in elderly mobile women [37]. Falls are the most common causes of emergency hospital admissions in those with PD due to the inherent pathophysiology of PD and a lower than normal femoral-neck bone mineral density (BMD), which may lead to osteoporosis [38]. The onset and progression of osteoporosis in individuals diagnosed with PD may be due to a limited exposure to sunlight, a deficiency in vitamin $\mathrm{D}$, having a classification of advanced PD, immobilization, hormonal imbalances, or poor dietary habits [39]. In postmenopausal women, exercise, with additional treatments (e.g., pharmacological supplementation), can maintain and even increase BMD in this population $[40,41]$. Exercise programs that incorporate muscle strengthening and balance can also potentially reduce the number of falls, thereby preventing hip fractures [42]. In women with PD, hip BMD is independently associated with leg muscle strength, as this muscle strength accounts for 8.8 to $10.6 \%$ of the variation observed in hip BMD [43].

\section{Conclusion}

Women with PD have greater levels of disability and reduced quality-of-life when compared to men with PD. Both aerobic and resistance exercise may elicit functional changes, including balance, in women diagnosed with PD. Exercise may also reduce chronic fatigue and increase or maintain BMD, thereby improving balance and decreasing the risk of hip fractures. More studies are needed that include an analysis of functional changes, using groups separated by gender, following some exercise intervention.

\section{References}

1. Moore GE, Durstine JL, Painter PL (2016) ACSM's exercise management for persons with chronic diseases and disabilities. ( $4^{\text {th }}$ edn $)$, Human Kinetics, Champaign, USA.

2. Taylor KS, Cook JA, Counsell CE (2007) Heterogeneity in male to female risk for Parkionson's disease. J NeurolNeurosurg Psychiatry 78(8): 905-906.

3. Elbaz A, Bower JH, Maraganore DM, McDonnell SK, Peterson BJ, et al. (2002) Risk tables for parkinsonism and Parkinson's disease. J ClinEpidemiol 55(1): 25-31.

4. de Lau LM, Verbaan D, Marinus J, van Hilten JJ (2014) Survival in Parkinson's disease. Relation with motor and non-motor features. Parkinsonism RelatDisord 20(6): 613-616.

5. Pinter B, Diem-Zangerl A, Wenning GK, Scherfler C, Oberaigner W, et al. (2015) Mortality in Parkinson's disease: a 38-year follow-up study. MovDisord 30(2): 266-269.

6. Xu J, Gong DD, Man CF, Fan Y (2014) Parkinson's disease and risk of mortality: meta-analysis and systematic review. Acta Neurol Scand 129(9): 71-79.

7. Gillies GE, Pienaar IS, Vohra S, Qamhawi Z (2014) Sex differences in Parkinson's disease. Front Neuroendocrinol 35(3): 370-384.

8. Shulman LM (2007) Gender differences in Parkinson's disease. Gend Med 4(1): 8-18.

9. Haaxma CA, Bloem BR, Borm GF, Oyen WJ, Leenders KL, et al. (2007) Gender differences in Parkinson's disease. J Neurol Neurosurg Psychiatry 78(8): 819-824. 
10. Cereda E, Barichella M, Cassani E, Caccialanza R, Pezzoli G (2013) Reproductive factors and clinical features of Parkinson's disease. Parkinsonism RelatDisord 19(12): 1094-1099.

11. Miller IN, Cronin-GolombA (2011) Gender differences in Parkinson's disease: clinical characteristics and cognition. MovDisord 25(16) 2695-2703.

12. Sato K, Hatano T, Yamashiro K, Kagohashi M, Nishioka K, et al. (2006) Prognosis of Parkinson's disease: time to stage III, IV, V, and to motor fluctuations. MovDisord 21(9): 1384-1395

13. Bjornestad A, Forsaa EB, Pedersen KF, Tysnes OB, Larsen JP, et al (2016) Risk and course of motor complications in a population-based incident Parkinson's disease cohort. Parkinsonism Relat Disord 22: 4853.

14. Colombo D, Abbruzzese G, Antonini A, Barone P, Bellia G, et al. (2015) The Gender Factor in wearing-off among patients with Parkinson's disease: a post hoc analysis of DEEP study. Sci World J 787451.

15. Martinez-Martin P, FalupPecurariu C, Odin P, van Hilten JJ, Antonini A, et al. (2012) Gender-related differences in the burden of non-motor symptoms in Parkinson's disease. J Neurol 259(8): 1639-1647.

16. Szewczyk-Krolikowski K, Tomlinson P, Nithi K, Wade-Martinis R, Talbot K, et al. (2014) The influence of age and gender on motor and non-motor features of early Parkinson's disease: initial findings from the Oxford Parkinson Disease Center (OPDC) discovery cohort Parkinsonism RelatDisord 20(1): 99-105

17. Solla P, Cannas A, Ibba FC, Loi F, Corona M, et al. (2012) Gender differences in motor and non-motor symptoms among Sardinian patients with Parkinson's disease. J NeurolSci 323(1-2): 33-39.

18. Picillo M, Amboni M, Erro R, Longo K, Vitale C, et al. (2013) Gender differences in non-motor symptoms in early, drug naïve Parkinson's disease. J Neurol 260(11): 2849-2855.

19. Cakit BD, Saracoglu M, Genc H, Erdem HR, Inan L (2007) The effects of incremental speed-dependent treadmill training on postural instability and fear of falling in Parkinson's disease. ClinRehabil 21(8): 698-705.

20. Duncan PW, Weiner DK, Chandler J, Studenski S (1990) Functional reach: a new clinical measure of balance. J Gerontol 45(6): M192-M197.

21. Duncan PW, Studenski S, Chandler J, Prescott B (1992) Functional reach: predictive validity in a sample of elderly male veterans. J Gerontol 47(3): M93-M98.

22. Shenkman M, Hall DA, Barón AE, Schwartz RS, Mettler P, et al. (2012) Exercise for people in early- or mid-stage Parkinson disease: a 16-month randomized controlled trial. Physther 92(11): 1395-1410.

23. Picelli A, Melotti C, Origano F, Neri R, Waldner A, et al. (2013) Robotassisted gait training versus equal intensity treadmill training in patients with mild to moderate Parkinson's disease: a randomized controlled trial. Parkinsonism RelatDisord 19(6): 605-610.

24. Volpe D, Signorini M, Marchetto A, Lynch T, Morris ME (2013) A comparison of Irish set dancing and exercises for people with Parkinson's disease: a phase II feasibility study. BMC Geriatr 13: 54.

25. Hackney ME, Earhart GM (2010) Effects of dance on gait and balance in Parkinson's disease: a comparison of partnered and nonpartnered dance movement. Neurorehabil Neural Repair 24(4): 384-392.
26. Duncan RP, Earhart GM (2012) Randomized controlled trial of community-based dancing to modify disease progression in Parkinson disease. Neurorehabil Neural Repair 26(2): 132-143.

27. Combs SA, Diehl MD, Staples WH, Conn L, Davis K, et al. (2010) Boxing training for patients with Parkinson's disease: a case series. PhysTher 91(1): 132-142.

28. Ebersbach G, Edler D, Kaufhold O, Wissel J (2008) Whole body vibration versus conventional physiotherapy to improve balance and gait in Parkinson's disease. Arch Phys Med Rehabil 89(3): 399-403.

29. Shenkman M, Morey M, Kuchibhatla M (2000) Spinal flexibility and balance control among community-dwelling adults with and without Parkinson's disease. J Gerontol A BiolSci Med Sci 55(8): M441-M445.

30. Winter DA (1995) Human balance and posture control during standing and walking. Gait Posture 3(4): 193-214

31. Pääsuke M, Mottus K, Ereline J, Gapeyeva H, Taba P (2002) Lower limb performance in older female patients with Parkinson's disease. Aging ClinExp Res 14(3): 185-191.

32. Paul SS, Canning CG, Song J, Fung VS, Sherrington C (2014) Leg muscle power is enhanced by training in people with Parkinson's disease: a randomized controlled trial. Clin Rehabil 28(3): 275-288.

33. Friedman JH (2009) Fatigue in Parkinson's disease patients. Curr Treat Options Neurol 11(3): 186-190.

34. Friedman JH, Abrantes A, Sweet LH (2011) Fatigue in Parkinson's disease. Expert Opin Pharmacother 12(13): 1999-2007.

35. Lou JS (2009) Physical and mental fatigue in Parkinson's disease: epidemiology, pathophysiology, and treatment. Drugs Aging 26(3): 195-208.

36. Abrantes AM, Friedman JH, Brown RA, Strong DR, Desaulniers J, et al. (2012) Physical activity and neuropsychiatric symptoms of Parkinson disease. J Geriatr Psychiatry Neurol 25(3): 138-145.

37. Taylor BC, Schreiner PJ, Stone KL, Fink HA, Cummings SR, et al. (2004) Long-term prediction of incident hip fracture risk in elderly white women: study of osteoporotic fractures. J Am GeriatrSoc 52(9): 14791486

38. Woodford H, Walker R (2005) Emergency hospital admissions in idiopathic Parkinson's disease. MovDisord 20(9): 1104-1108.

39. Invernizzi M, Carda S, Viscontini GS, Cisari C (2009) Osteoporosis in Parkinson's disease. Parkinsonism RelatDisord 15(5): 339-346.

40. Li WC, Chen YC, Yang RS, Tsauo JY (2009) Effects of exercise programmes on quality of life in osteoporotic and osteopenic post-menopausal women: a systematic review and meta-analysis. ClinRehabil 23(10): 888-896.

41. Nikander R, Sievänen H, Heinonen A, Daly RM, Uusi-Rasi K, et al. (2010) Targeted exercise against osteoporosis: a systematic review and metaanalysis for optimising bone strength throughout life. BMC Med 8: 47.

42. Howe TE, Rochester L, Jackson A, Banks PM, Blair VA (2007) Exercise for improving balance in older people. Cochrane Database Syst Rev 9(11): CD004963.

43. Pang MY, Mak MK (2009) Muscle strength is significantly associated with hip bone mineral density in women with Parkinson's disease: a cross-sectional study. J Rehabil Med 41(4): 223-230. 
This work is licensed under Creative

Commons Attribution 4.0 Licens

DOI: 10.19080/JGWH.2017.02.555592
Your next submission with Juniper Publishers will reach you the below assets

- Quality Editorial service

- Swift Peer Review

- Reprints availability

- E-prints Service

- Manuscript Podcast for convenient understanding

- Global attainment for your research

- Manuscript accessibility in different formats

( Pdf, E-pub, Full Text, Audio)

- Unceasing customer service

Track the below URL for one-step submission https://juniperpublishers.com/online-submission.php 